\title{
PETRAŻYCKI'S PSYCHOLOGICAL JURISPRUDENCE: ITS ORIGINALITY AND IMPORTANCE*
}

\section{F. S. C. Northrop $\dagger$}

Professor Babb's abridgment into one volume and his English translation of Petrażycki's mature legal works and Professor Timasheff's concise Introduction give the essentials of the context and content of Petrażycki's legal science. ${ }^{1}$ The context is important for understanding the theory. The contents demonstrate Petrażycki's originality and establish him as a legal thinker of first rate importance.

The physical context is that of Central and Eastern Europe between the latter part of the nineteenth century and the end of World War I. Petrażycki was born in 1867 in the predominantly Polish culture of the area which had been annexed by Russia in 1772 . He first studied medicine and then took a brilliant degree in law at the University of Kiev. This degree won him admission to an advanced research seminar in law at the University of Berlin. There he mastered the traditional methods of legal scholarship and published in German two legal works in the traditional manner which he was later to refer to as the "dogmatic" method. Only in the appendix, entitled "Civil Policy and Political Economy," of the last of the foregoing works did he show signs of his dissatisfaction with the traditional legal science. In 1898 he was made professor of law at the University of St. Petersburg where he developed his final theory and remained until the Bolshevik Revolution. In 1921 he emigrated to Poland where he was professor of law at the University of Warsaw.

His intellectual context, therefore, was that of post-Kantian and post-Hegelian continental Europe after certain very important epistemological and methodological lessons concerning the nature of scientific knowledge had been learned from Kant, and when the development

* The author is gratefully indebted to the Wenner-Gren Foundation for Anthropological Research, Inc., for grants which have made this study possible.

† Sterling Professor of Philosophy and Law, Yale Law School.

1. Law and Morality. By Leon Petrazycki. Translated by Hugh W. Babb with an Introduction by Nicholas S. Timasheff. 20th Century Legal Philosophy Series: Vol. VII. Cambridge : Harvard University Press, 1955. Pp. 335. \$7.50. 
of cultural and legal positivism and experimental psychology had indicated certain weaknesses in the Kantian and Hegelian idealistic philosophy of morals and law. In his analysis of the mathematical physics of Newton, Kant taught continental scientists and philosophers two things: (1) the necessity in science of theoretically contributed concepts specified deductively, as well as inductively given data; (2) the naive realistic epistemological error of reifying the theoretically contributed nouns of scientific language into supposedly concrete, externally existing objects. This naive realistic epistemological error is what Petrażycki meant, undoubtedly, when he described the traditional legal science, including legal positivism as well as the prevalent Hegelian idealistic philosophy of law, as "dogmatic." Petrażycki's problem became, therefore, that of finding the theoretically designatible and empirically verifiable concrete entities and relations to which the abstract nouns of law, such as "obligation," "right" and "sanction," refer for their scientific meaning. At this point the epistemological and methodological lessons concerning scientific method, which were learned from Kant, combined with the late nineteenth century's interest in experimental psychology.

English and especially American readers should find Petrażycki's final, mature legal science of considerable interest. It gives an insight into Russian scientific, philosophical and legal thought in the opening decades of this century immediately before the Bolshevik Revolution. Petrażycki exhibited at that time the same dissatisfaction with traditional legal science that appears later in the United States with the legal realists and Professor Roscoe Pound's sociological jurisprudence and in Austro-Hungary with Ehrlich. But, instead of turning primarily to social science, which he does secondarily, Petrażycki finds in psychology the basic facts and concepts in terms of which law is to be understood and analyzed. In this respect his legal theory is near to that of the psychologically grounded sociological jurisprudence of Underhill Moore's later work. Petrażycki is like Moore and Moore's colleague, the psychologist, Hull, in his insistence upon the importance of making explicit the basic concepts of his science and deriving all other concepts from them by the logical methods of definition and formal implication. But whereas Moore's psychological jurisprudence was behavioristic, following Watson, Pavlov's physiology and Hull, Petrażycki's is introspective. A reading of Law and Morality will show that it is none the less experimental or theoretically rigorous because of this. ${ }^{2}$ Yet Petrażycki's introspective psychology is not that of Anglo-

2. Professor Timasheff suggests, in his Introduction to Law and Morality, that Petrazycki's introspective psychology is formally equivalent to the current behavioristic 
American introspective psychologists such as Locke, Hume, Bentham or James; nor is his psychological theory of morals and law like that of the psychological theory of interests of the Americans Ralph Barton Perry and Roscoe Pound, or the German Ihering.

Petrażycki's psychological jurisprudence differs from that of Underhill Moore in one other important respect. Whereas Moore left all strictly ethical concepts out of legal science, for Petrażycki the ethical concept of obligation is basic to both the theory of morals and the theory of law. At this point he is undoubtedly following Kant with the latter's emphasis upon obligation or duty as the basic concept in ethics. At this point also Petrażycki's jurisprudence is near to that of Morris and Felix Cohen. Nevertheless he does not agree with Kant or the Cohens and G. E. Moore in affirming that good is an a priori or primitive concept in legal science, thereby making ethics the foundation of law. Instead, obligation is an empirical concept finding its meaning in certain theoretically designatible and empirically verifiable factors in the psychological nature of any human being. At this point Petrażycki succeeds in constructing a logically precise and connected psychological jurisprudence which combines the psychological emphasis of Ihering, James, Pound, Perry and Underhill Moore with the ethical insights of Morris and Felix Cohen and the English empiricist, G. E. Moore, in a way that no other continental, British or American legal thinker has done.

Also whereas Bentham, Ihering, Perry and Underhill Moore began with a specific psychological theory and fitted their analysis of the subject matter of law into this, Petrażycki begins with an inductive, empirical investigation of what distinguishes the subject matter of law from other somewhat similar subjects, such as morals and aesthetics, and then creates a new science of psychology to account for the unique character of legal phenomena. Thus Petrażycki has something exceedingly important to teach anyone about law quite apart from his psychology and his psychological jurisprudence.

reflex theory. This judgment would seem to leave the "action ideas" of Petrazycki's psychology out of account. To establish a formal equivalence it is necessary to modify the Hull-Moore reflex psychology by adding (1) the conception of the human nervouis system as a teleological (i.e., negative feed-back) mechanism as suggested by Rosenblueth, Wiener and Bigelow and (2) the theory of cortically "trapped universals" as suggested by McCulloch and Pitts. The role of the "trapped universals" between sensory and motor neurons is formally equivalent to that of the "action ideas" between the "passive" and "active" components of "blanket impulsions" in Petrazycki's introspective psychology. For an exposition of (1) and (2) above and their application to legal science, see Northrop, Ideological Man in His Relation to Scientifically Knozen Natural Man in Ideological Differences and Wordd ORder (Northrop ed. 1949). See also Northrop, Contemporary Jurisprudence and International Law, 61 YALE L. J. 641 (1952). 


\section{The Unique Factor in Legal Phenomena}

Petrażycki became convinced at Berlin that traditional legal science failed to be scientific because it lacked a clear concept of its subject matter. This showed in certain jurists who, seeing that law was normative, tended to identify it with morality without any clear conception of the difference between morals and law. It showed also in the jurisprudence of interests of Ihering and others who, noting that different interests came to expression in litigation, failed to provide the criterion which distinguishes economic wants or interests from legal wants and interests on the one hand or merely moral wants and interests on the other. It showed again in sociological jurists who, while finding the source of law in society, failed to provide a scientific concept distinguishing social phenomena which are legal from those which are economic, aesthetic or merely ethical in the generic sense of the word "ethical."

Petrażycki's positive solution appears if we concentrate on what distinguishes a merely moral relation of $A$ to an object $B$, from a legal relation. His conclusion is that both impose an obligation on $A$, but but that the obligation is unilateral in the case of a moral relation and bilateral in the case of a legal relation. The unilateral character of a merely moral relation between two persons $A$ and $B$ is shown by two examples from the New Testament to which Petrażycki refers: (1) Jesus' injunction to turn the other cheek, and (2) "But I say unto you: resist not evil." Why are these moral relations unilateral? Petrażycki's answer is that when $A$ enters into a moral relation with $B$, by ascribing to himself the obligation to act in a certain way with respect to $B$, he does not ascribe the converse right to $B$ to demand such action on $A$ 's part. In other words, in a moral relation between $A$ and $B, A$ is under an obligation to himself to behave in a certain way with respect to $B$ without $B$ having the converse right to such behavior from $A$. Legal relations on the other hand are bilateral because in them there is no such thing as $A$ having an obligation to perform in a certain way with respect to $B$ without $B$ having the converse right to such performance on the part of $A$. Petrażycki uses the term "ethics" to represent any moral relation or experience in which an obligation occurs. When that obligation is unilateral, we have the branch of ethics termed "morals"; when it is bilateral, we have the branch of ethics termed "law."

It is to be noted that Petrażycki's distinction between law and morality reverses the usual conception of the ethical merits of these two subjects. It is customary to regard law as a weaker and lower form of ethics than morality. Petrażycki's analysis indicates that there is a 
sense in which law is a higher ethics than morals. This becomes evident when one notes that in a unilateral obligation one gives no right to the object of one's ethical act. If I in one instance, having been slapped on one cheek, turn the other in accordance with Jesus' injunction, I in no way give the other party the right to have me turn the other cheek every time or any time he may choose to slap me. In this sense morality is a cheaper ethics than law. For in law any time that I obligate myself with respect to an object $B$, I automatically ascribe $^{3}$ to $B$ the right to have this obligation carried through by me. Thus legal obligation carries with it a price, if Petrażycki's analysis be correct, which moral obligation does not entail. This may explain why people are less willing to obligate themselves as fully in law as they may do in personal morals. It may also explain why morality tends to be associated with generosity, whereas law is on more of a quid pro quo basis. In any event, the present writer finds Petrazycki's analysis of the distinction between morals and law convincing.

Aesthetics falls outside ethics, according to Petrażycki, because aesthetic relationships and judgments, while normative, do not impose an obligation. Thus when $A$ asserts $B$ to be beautiful or that $B$ behaves in accordance with good form, $A$ in no way obligates himself either unilaterally or bilaterally.

Having thus found both the generic and the differentiating properties of legal relations and experiences, Petrażycki then turns to the question of the source of their authority. Why does any person $A$ enter into an obligatory relation to an object $B$ for which $A$ pays the price of ascribing to $B$ the right to specific conduct on $A$ 's part in accordance with that obligation?

The traditional legal science in Petrażycki's time, as in ours, found the answer in "power" or "the will of the sovereign." 4 Petrażycki sees, however, that these words are merely metaphors. To suppose that they answer the question of the source of bilateral obligation is to be guilty of the naive epistemological error of reifying an abstract projected construct into a concrete entity or will. This clearly is scientific nonsense.

Where then is the source of moral and legal obligation to be found? What are the concrete, empirically observable and precisely conceptualizable phenomena from which the abstract nouns of moral obliga-

3. In this emphasis upon "ascription," Petrazycki foresaw much of what the Oxford philosophical analyst and legal positivist, Professor H. L. A. Hart, now emphasizes. Petrazycki was not, however, a legal positivist.

4. Even Kant, notwithstanding his emphasis upon the naive realistic epistemological error of giving abstract nouns an external, objective, concrete existence, distinguished law from ethics by making the source of the sanction for law external, whereas in morals it was private and internal to the concrete individual person. 
tion and legal right derive their scientific meaning? Clearly it is not from "society," since society itself is not a concrete entity but is instead a theoretical construct. We do not see society after the manner of a person looking down on a geographical terrain from the vantage point of an airplane. Human beings do not have muscles and bones tying them to one another to form a concrete social organism with physical power after the manner in which the bones and tissues of the person's body bind his anatomical parts into a physical organism with muscular power. Instead, the concrete and real facts at the basis of both society and legal relations must be found in the individual person alone and in his relations to other concrete or subjectively projected objects to which the concrete individual commits himself. Hence psychology, rather than official positive law or even sociology, can alone provide the basic facts and concepts of legal science.

\section{The Basic Elements of Petrażycki's Psychological JURISPRUDENCE}

Empirical psychologists such as Locke, Hume and Bentham and continental psychological jurists, such as Ihering, had tended to conceive of colors, pains, pleasures, interests and wants in merely their passive relationship to the self as presented data. Or if, after the manner of Ihering at times and the later pragmatic instrumentalists, they emphasized the activity of the person, then the passive component was overlooked, and all psychological and legal experiences were made instrumental to a future end and in this sense always teleological. Petrażycki noted, however, that either account gives only one facet of concrete, empirical personal experience, when in fact there are two. This passive-active character of any specific person's concrete experience Petrażycki terms an "impulsion." Impulsions, therefore, become the elementary entities of his psychology and legal science.

Impulsions fall into two major classes: (1) "specific" and (2) "blanket" or "abstract." An impulsion is specific if the effect of its passive component upon its active component is the fulfillment of a specific biological function. An example is when the passive sensation of hunger results automatically and unconsciously in the biological act of getting and eating food. An unreflective hateful response to a stimulus is another example. An unreflective benevolent response, which Petrażycki terms love, is a third instance.

In blanket or abstract impulsions, conscious awareness of what one is doing is present. The passive factor does not determine the active factor automatically. This additional factor Petrażycki terms the "ac- 
tion idea." Furthermore the content of the active component is left open. Hence the word "blanket" or "abstract." Thus specific impulsions are passive-active experiences unaccompanied by action ideas. Blanket impulsions are passive-active experiences accompanied by action ideas. They are, in other words, passive-active experiences in which the idea of the conduct associated with the impulsion "defines the character and direction of our conduct." 5

The error of the hedonistic psychological jurisprudence of Bentham and the jurisprudence of interests of Ihering or Pound in its more passive formulation now becomes evident. Such a jurisprudence tends to identify the psychological basis of law with a passively sensed datum such as pleasure or an inspected want or interest. Similarly the jurisprudence of interests in its alternative active, instrumentally teleological formulation has no passive component mediated to its active component by an action idea to provide the psychological basis for a person actively ascribing (a) to himself an obligation and (b) to an object other than himself the right to have a specified form of active behavior fulfilled. In short, the traditional psychological jurisprudence in either its merely passive or its merely active formulation, being without both passive and active components in the psychological nature of man and an action idea relating one component to the other component, is left, of necessity, without any psychological basis for either moral or legal obligation. Hence the necessity in traditional jurisprudence of committing the naive realistic epistemological error of reifying abstract nouns like external "power" or "the will of the sovereign" into supposedly concrete entities in order to account for social or moral obligation or for legal obligation of any kind.

It remains to give the psychological definitions of those particular experienced impulsions which are legal experiences. When, in any blanket impulsion, given a particular passive component, a person $A$ in the active component of the concrete impulsion commits himself to conduct guided by an action idea which imposes an obligation upon himself with no converse right of the object of the impulsion to that particular active response, the impulsion is that of a moral relationship and experience. When the action imposed by the action idea carries with it not merely obligation upon $A$ but also the converse right of $B$ to that type of active response from $A$, then the relationship is legal and the psychological experience is a legal one.

Impulsions accompanied by action ideas Petrażycki also calls "intellectual impulsions." These may be of two kinds: (a) teleological,

5. Petrazycki, op. cit. supra note 1 , at 27. 
and (b) non-teleological. A blanket impulsion is teleological when the action idea within it takes the form of "action in order that $x$," where $x$ refers to something in the future. It is non-teleological when the action idea takes the form of "action because of $x$," where $x$ refers to something in the past or present. Because of this distinction within possible blanket impulsions, Petrażycki affirms that those ethical or legal theories are erroneous which conceive of all ethical or legal norms instrumentally as teleological or purposive. Some ethical or legal relations are of the latter type, others are not.

So far Petrażycki's legal science is merely formal. It refers, to be sure, to concrete psychological experiences of any human being. In this sense it is concrete. But the content of the action ideas in any moral or legal impulsions varies from culture to culture and even, as Petrażycki notes, from person to person. All people in any culture or society are beings experiencing impulsions. All people, also, experience those blanket impulsions whose action ideas impose obligations on $A$ together with the right of $B$ to a fulfillment of that obligation by $A$. Hence every society and culture possesses law.

Although any legal relation involves a specific concrete person and his bilateral imperative impulsions, it by no means follows that the objects of legal relations must be such concrete persons. The action idea may take as its object inorganic nature, as it does in most primitive and Oriental societies where the people and their sages identify good conduct and good law with "harmony with nature." The action idea may also take as its object an animal other than man. When, for example, I take care of my dog in such a way that I obligate myself to feed him and accept his barking as the calling of my attention to his right to be fed by me, I am committing myself to a legal obligation. This example, which is the writer's, illustrates two important practical consequences of Petrażycki's legal science. First, it enables one to interpret official positive laws about cruelty to animals in their obvious meaning as a relation between a person and a non-human animal. Second, it shows that, as with the sociological jurisprudence of Ehrlich, seven-eighths of the law is outside official positive law.

Petrażycki expresses the latter consequence of his psychological jurisprudence by dividing law into (a) "positive law" and (b) "intuitive law." Positive law in his usage must not be taken to mean what it means for Ehrlich or for legal positivists such as Austin or Kelsen; instead, positive law in Petrażycki's sense is any bilateral blanket impulsion which, in any person's psychological experience of it, finds the justification for its action idea in some authority or reason outside that experience itself. Official positive law is but one small portion 
of such bilateral blanket impulsions. Intuitive law, on the other hand, is a bilateral imperative blanket impulsion whose action idea finds its justification solely in the immediate present experience of the impulsion itself. In other words, it is a bilateral imperative impulsion which to the person experiencing it seems to be immediately, and hence intuitively, self-evident.

Intuitive law, according to Petrażycki, may be ethically inferior to "positive law." This occurs frequently when the person is insensitive morally and legally or is less reflective with respect to the action ideas of his impulsions than the general run of people in his community or in other communities. What actually happens, Petrażycki notes, in most intuitive morality or law is that the person reflects in his immediately experienced intuitions the deposited cultural norms of his past when these norms have taken on a purely mechanical form without much sensitivity to the subtle factors in human experience which are their origin.

The action ideas in legal impulsions may take as their objects, however, theoretically constructed factors rather than nature or a specific concrete person or non-human animal. Hence arise legal concepts such as "corporate personality." In short, the object to which a person relates himself in a legal experience may be what Petrażycki terms a "phantasmic projection." Furthermore, even when the legal object is a concrete, external person or thing, the legal right ascribed to that concrete object is not an intrinsic predicate of the object, but is instead a phantasmic projection. Failure (1) to note, therefore, that all legal concepts are phantasmic projections and (2) to trace all phantasmic projections back to the action ideas of the passive-active blanket impulsions which are their concrete psychological basis is the error of traditional positivistic or idealistic legal theory, i.e., of dogmatic jurisprudence.

Legal impulsions analyze further, according to Petrażycki, into four major factors: (1) action ideas, (2) subject ideas, (3) ideas of relevant facts, and (4) ideas of normative facts. The nature of action ideas has been indicated above. Subject ideas refer to the action ideas as they bear upon subjects qua subject, and differentiate into the subjects of obligations and the subjects of rights. Ideas of relevant facts are ideas of events such as the moment I entered into a legal relation with my dog, the occasion when an official legislative statute was passed or the moment when the judge gave a specific decision. Ideas of normative facts, on the other hand, refer to relationships between the person who obligates himself and the right of the object which that legal obligation entails. Thus ideas of normative facts 
are legal propositions or rules rather than ideas of legal events. One of the main points made by the contemporary Scandinavian school of legal thinkers, who have been greatly influenced by Petrażycki, against the American legal realists ${ }^{6}$ is that, in the latter's conception of law as the prediction of future legal events, the American legal realists fail to distinguish "ideas of relevant facts" from "ideas of normative facts." Without the (a) ascription of the normative rule as well as the (b) legal event, there would be no such thing as the tie of obligation upon the subject and the converse right of the object; in short, there would be no such thing as either law or society. Again let it be remembered, people are not tied together to form interpersonal obligations and rights and social institutions by physical bones, rods or muscles; they only tie themselves together legally and socially by means of bilaterally imperative action ideas to which they commit themselves. To have seen this and to have shown how it can be made meaningful is certainly the great merit of Petrażycki's psychological legal science.

\section{Some Queries}

Even so, is not his psychological jurisprudence a purely formal theory-almost as formal as the legal positivism to which he objects of a British empirically minded Austin or a continental rationalistically minded Kelsen? To be sure, it goes beyond legal positivism in not having to resort either to "power" on the one hand or to an historically or dogmatically assumed Gruntnorm on the other to get effective positive law into being. Petrażycki's psychological jurisprudence, like Ehrlich's sociological jurisprudence, finds the source of the sanctions and effectiveness of law within the basic concepts of legal science itself, not in something foreign to legal norms and concepts such as a naively reified "social power."

Even so, is there any method or criterion in Petrażycki's, or any other, psychological jurisprudence for telling us what the content of any specific action idea will be or whether the content of the normative facts of a given official positive law, a given de facto sociological living law (in the sense of Ehrlich) or a given person's intuitive law is in need of reform or, in other words, good or bad? In so far as Petrażycki answers this question with respect to official positive law, it is by an appeal to the empirical living law of sociological jurisprudence. It is at this point that, after constructing his legal science primarily in terms of psychological factors, he turns implicitly and secondarily to sociological jurisprudence, without specifying the con-

6. See Hart, Definition and Theory in Jurisprudence, 70 L.Q. REv. 37, 39 (1954). 
crete factors by means of which the private bilateral imperative impulsions of psychological jurisprudence become shared to produce the social bilateral imperative impulsions of sociological jurisprudence.

Furthermore, if the "sharing" is not itself to remain a mere metaphorical phantasm, emphasis must be placed upon communication between people by means of symbols, whereby they convey the specific action idea content of their respective private and local bilateral imperative impulsions to one another. By this concrete means psychological jurisprudence becomes socially and culturally transformed into sociological and anthropological jurisprudence, and private local legal experiences become socially, officially and culturally imperative, effective and powerful. This means that both society and the law of a society get their unity, power and sanction not from an external physical force added to the normative content of their particular action ideas, but instead a nation and its official positive law is able to draw physical police and military power to itself only because of the symbolically communicated sharing of common action ideas with specific bilateral imperative content by its several concrete individual psychological persons.

It is in clarifying the concrete instrumentalities of this communicated sharing that contemporary cybernetics and communication engineering become important for legal science. It may be noted also that the foregoing analysis of the relation between psychological and sociological jurisprudence which was implicit, if not explicit, in Petrażycki's theory of legal science undermines not merely the legal positivists and Kant's theory of the external sanctions of legal obligation, but also the prevalent power politics theory of the nation and of international relations. All of the latter theories derive their plausibility from the naive realistic epistemological error of confusing abstract nouns referring to phantasmic projections with concrete entities external to individual persons and individual bilateral imperative experiences.

Even with the foregoing clarification of the relation between Petrażycki's primary appeal to psychological jurisprudence and his secondary appeal to sociological jurisprudence, one final crucial question still remains which no contemporary legal thinker can escape: Assuming the content of the normative facts in the intuitive law of any person or in the living law of any society to be what they are, what scientific criterion is there for passing judgment upon them as good or bad, or in need of reform? Clearly people the world over today, especially in the so-called underdeveloped areas, are questioning and reforming both their intuitive psychological and their social living law norms. Petrażycki notes that the average person thinks he has a 
basis for judging both the official positive and the living law of his society or any other in terms of his own private intuitive law. Petrażycki adds, however, as previously noted, that often a person's intuitive, moral and legal convictions may be less sensitive morally and legally and of lower ethical quality than those of the general run of people in his community. Hence, to go to the psychological intuitive moral and ethical experiences of the individual will not do. It is Petrażycki's thesis, furthermore, that so-called natural law is merely intuitive law. Before noting this error, one conclusion may be stated. In Petrażycki's psychological jurisprudence, even when its reaction to sociological jurisprudence is clarified, one is left normatively with a merely formal system, the content of which is a cultural historical or psychological accident. One has no criterion of when the content of the intuitive or the positive social living or official norms within the system is the good or the scientifically correct one. Yet this criterion must be specified by any science of law which aims, as Petrażycki aimed, to provide a scientific theory of legal reform.

Is it not clear that for such a criterion legal science must (a) develop a theory of how the action ideas within legal impulsions get their content, and (b) specify the scientific method of distinguishing between content which is good and content which is bad ? ${ }^{7}$ The latter method, if it is not to be circular and question-begging, must be such moreover as to escape both the sophistic relativism of psychological jurisprudence and the cultural relativism of sociological jurisprudence. To assert that such a non-relativistic criterion exists for judging (a) psychological intuitive law, (b) official positive law and (c) the living law of sociological jurisprudence is the thesis of natural law jurisprudence. Petrażycki's identification of natural law, therefore, with psychological intuitive law is erroneous. The specification of the scientific method by which the thesis of natural law jurisprudence is to be implemented is the major task of contemporary legal science. Petrażycki's psychological jurisprudence is a necessary, even though not a sufficient, condition for this undertaking.

7. Professor Pitirim A. Sorokin informs the writer that in lectures which he attended at St. Petersburg after Law and Morality was published, Petrazycki was concerned with this very problem. 